J. Japan. Soc. Hort. Sci. 46(4) : 509-514. 1978.

\title{
The Role of Leaves in the Induction of Dormancy of Gladiolus Corm
}

\author{
Haruo Konoshima and Yotaro Tsukamoto* \\ Faculty of Education, Shiga University, Otsu, Shiga \\ * Faculty of Agriculture, Kyoto University, Kyoto
}

\begin{abstract}
Summary
1. The weight of corms from plants of which the leaf bases had been wrapped with aluminium foil from the sprouting stage or the three-leaf stage was found to be significantly heavier than that of control corms.

The difference in weight was maintained up to the end of plant growth. On the other hand, when the sheath leaf was removed, the weight of corms significantly decreased.

2. A significantly earlier sprouting was observed in corms from plants grown with shading at the leaf base, and corms from plants, from which sheath leaves had been removed, grown with shading at the base of the leaf showed a similar sprouting trend.

On the contrary, sprouting of corms from plants of which the sheath leaves had been removed, was delayed, as it was in control corms.

3. The amounts of inhibitors, at $\mathrm{Rf}$ valued $0.5-0.8$ on paper chromatograms developed with isopropanol: ammonium: water $(10: 1: 1 \mathrm{v} / \mathrm{v})$, did not decrease in corms from plants without sheath leaves.

On the other hand, shading of the leaf bases resulted in a decrease of inhibitor at $\operatorname{Rf} 0.5-0.8$.

4. The extract from leaf bases sampled a week after the shading treatment at the leaf base showed a smaller amount of inhibitors at $\operatorname{Rf} 0.5-0.8$.
\end{abstract}

\section{Introduction}

Some endogenous inhibitors have been observed to increase in light; i.e. neutral inhibitors (7), acid inhibitors (4) and gibberellin-inhibitors (2), etc.

Recently Tucker et al. (9) reported that exposure of Xanthium strumarium to far-red light resulted in an increase in extractable ABA.

Volio and Schwabe (10) dealt with the correlation between changes in endogenous inhibitors induced on exposure to long days and dormancy in Lunularia.

In several species of woody plants, Wareing et al. showed that bud dormancy was induced by an endogenous inhibitor produced in leaves on exposure to short days $(6,1)$.

Konoshima and Tsukamoto demonstrated in a previous paper (3) that sprouting was promoted in gladiolus corms from the plants

Received for publication March 10, 1977 of which the leaf bases or leaf tops had been shaded or the leaves had been treated with photosynthesis-inhibitors, and that a decrease in the amount of endogenous inhibitors was found in extracts from corms.

Furthermore, the results in the previous paper made it clear that inhibitors decreased in two $\mathrm{Rf}$ value differently corresponding to the two different treatments, and that weight of corms also showed a difference depending on the treatment.

In this paper, these differences are investigated in detail.

\section{Materials and methods}

Corms of Gladiolus hybrida Hort.cv. Snow Princess were used. Corms $9 \mathrm{~g}$ in weight were planted on May 18, 1974.

Three lots of treatment were prepared, (1) wrapping the leaf bases including the sheath leaves with aluminium foil, (2) removing the sheath leaves, (3) wrapping the leaf bases 
with aluminium foil after removing the sheath leaves.

The treatments were started either at the sprouting stage (on May 31) or at the threeleaf stage (on June 22).

The leaf base was wrapped with aluminium foil to a height of $20 \mathrm{~cm}$ from the earth, and in lot (3), the sheath leaves were cut off.

The daughter corms were harvested on October 18, but additionally corms grown under natural conditions and those grown by shading the leaf bases from the three leaf stage were sampled to measure the fresh weight of corms nine times, on June 29, July 10, July 31, August 20, September 10, September 30, October 18, November 6 and on December 23.

All daughter corms after harvest were planted in vermiculite for the sprouting test on October 25, and maintained at $15-25^{\circ} \mathrm{C}$ during the test. Each group consisted of 10 corms.

Corms were sampled for extraction a month after harvest, and leaves were also taken for sample a week after the treatment on the three-leaf stage.

The method of extraction and purification of endogenous growth regulators from corms were reported in the previous paper (3). The extract from leaves ( $5 \mathrm{~g}$ in fresh weight) was first washed with petroleum ether in order to remove chlorophylls.

The activities of endogenous growth regulators were tested using the rice seedling test which was reported by Ogawa (5). The data of the test are averages of three assays each.

\section{Results}

Effect of shading at the base of the leaf on the change in weight of corms are shown in Fig. 1.

No significant difference in weight of corms was observed a week after the treatment between corms from the plants of which the leaf bases had been wrapped with aluminium foil from the three-leaf stage and those from intact plants.

The weight of corms from plants grown with shading at the base of the leaves was found to be significantly heavier than that of control corms on the 60 th day after the treat-

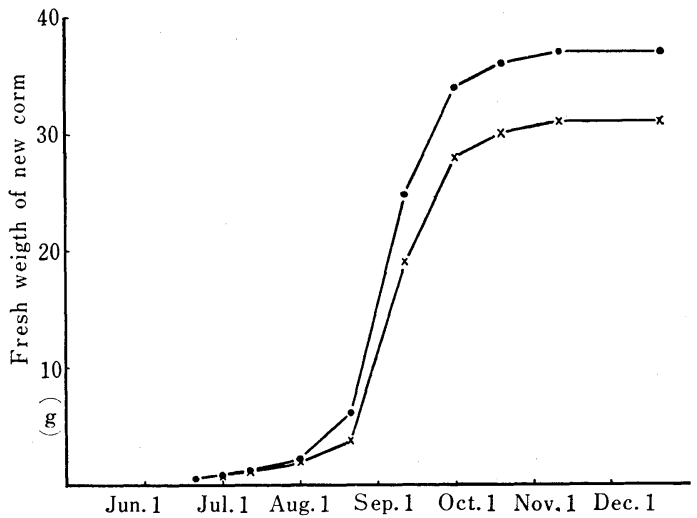

Fig. 1. Effects of shading at the base of the leaves on the change in weight of gladiolus corms.

- shading at the base of the leaves from the three leaves stage

$x-\times$ control

Table 1. Effects of shading at the base of the leaves or removal of the sheath leaves on the fresh weight of gladiolus corms.

\begin{tabular}{|c|c|}
\hline treatment & fresh weight $(\mathrm{g})$ \\
\hline \multicolumn{2}{|l|}{ from sprouting stage } \\
\hline removal of the sheath leaves & 16.7 \\
\hline $\begin{array}{l}\text { shading at the base of the leaves, } \\
\text { the sheath leaves being removed }\end{array}$ & 22.7 \\
\hline shading at the base of the leaves & 33.3 \\
\hline from the three leaves stage & \\
\hline removal of the sheath leaves & 26.0 \\
\hline $\begin{array}{l}\text { shading at the base of the leaves, } \\
\text { the sheath leaves being removed }\end{array}$ & 28.3 \\
\hline shading at the base of the leaves & 36.0 \\
\hline control & 30.0 \\
\hline
\end{tabular}

ment, and the difference in weight, about $5.5 \mathrm{~g}$ at the maximum growth period, was maintained up to the end of plant growth, December 23.

The thickening of corms from plants grown with shading at the leaf base and that of control corms ceased in the same period.

Therefore, the increase in weight of corms from plants grown with shading at the base of the leaves was not caused by the acceleration of plant growth, but probably by the activation of translocation to the corms.

The weight of corms at harvest in all cases is shown in Table 1.

When the leaf bases were shaded from the sprouting or the three-leaf stage, a heavier weight of corms was observed than in the control. On the other hand, when the sheath leaf was removed, the weight of corms sig- 


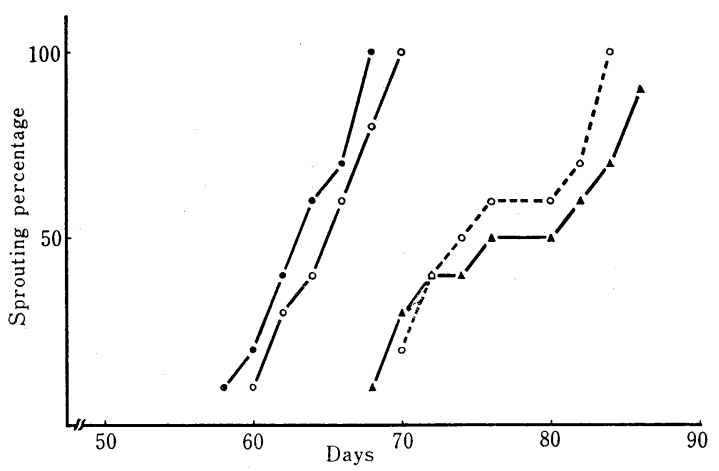

Fig. 2. Effects of shading at the base of the leaves or removal of the sheath leaves from the three leaves stage on the sprouting of gladiolus corms.

- shading at the base of the leaves

$\bigcirc-\bigcirc$ shading at the base of the leaves, the sheath leaves being removed

$\bigcirc \cdots \bigcirc$ removal of the sheath leaves

$\Delta$ - $\mathbf{\Delta}$ control

nificantly decreased.

If the leaf base, from which the sheath leaf had been removed, was shaded, the weight of corms recovered slightly.

The results of the sprouting test of corms from plants treated from the three-leaf stage are shown in Fig. 2.

A significantly earlier sprouting was observed in corms from plants grown with shading at the leaf base, and corms from plants grown with shading at the base of the leaf but lacking sheath leaves, showed a similar sprouting trend.

On the other hand, sprouting of corms from plants devoid of the sheath leaves was delayed as much as in control corms.

The sprouting test of corms from plants treated at the time of sprouting was similarly promoted to corms from plants which had been treated at the three-leaf stage, though both corms from plants without sheath leaves and the control corms sprouted later.

The results of the rice seedling test on chromatograms of the extract from new corms carried out a month after harvest are shown in Fig. 3.

Two zones of inhibition occurred at $\operatorname{Rf} 0.1$ -0.3 and Rf $0.5-0.8$ in extracts from corms grown under natural condition.

The inhibitor at $\operatorname{Rf} 0.5-0.8$ is usually called the "inhibitor $-\beta$ complex".

The extract from new corms from plants
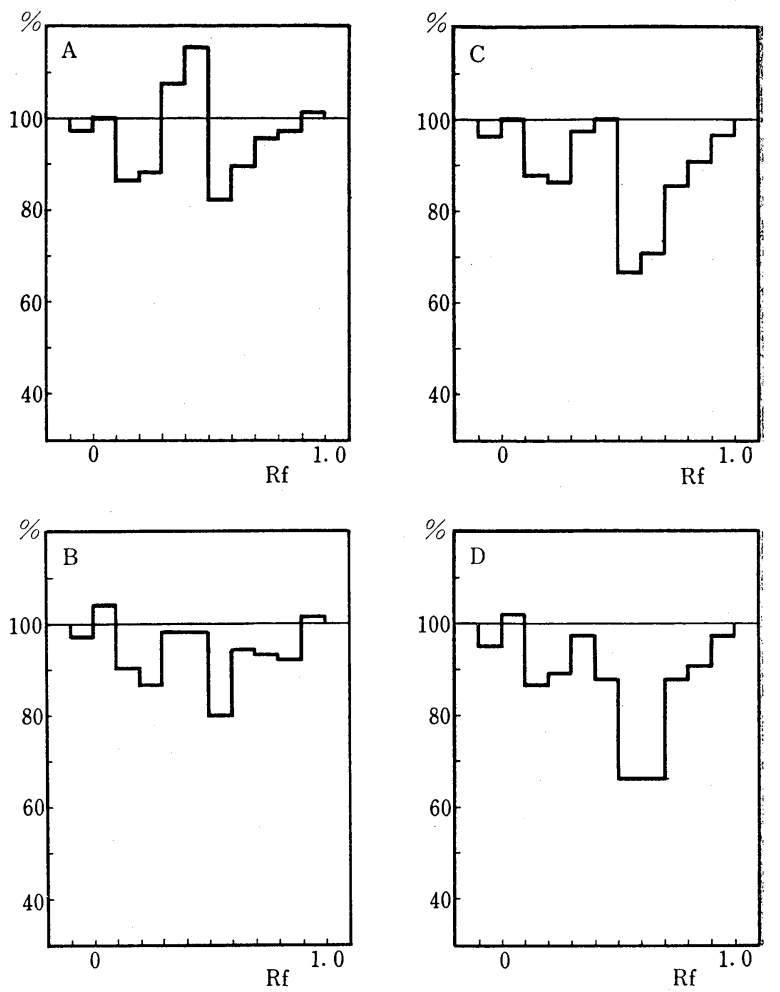

Fig. 3. Results of rice seedling test for extracts from gladiolus corms carried out a month after harvest.

A. shading at the base of the leaves

$B$. shading at the base of the leaves, the sheath leaves being removed

C. removal of the sheath leaves

D. control

without sheath leaves showed the two inhibitory zones at $\operatorname{Rf} 0.1-0.3$ and $\operatorname{Rf} 0.5-0.8$ as did that from the control corms.

On the other hand, shading of the leaf bases resulted in a decrease of inhibition at Rf $0.5-0.8$.

Fig. 4 shows the results of bioassay of the extracts from leaves sampled a week after the treatment.

The extract from sheath leaves of the plant grown under natural condition showed two inhibitory zones at $\operatorname{Rf} 0.1-0.3$ and $\operatorname{Rf} 0.5$ 0.8 , though the extract from the leaf bases of the same plant predominantly showed a single inhibitory zone at Rf $0.5-0.8$.

When the leaf bases were shaded, the inhibitory zone at $\operatorname{Rf} 0.5-0.8$ was significantly decreased in both extracts from sheath leaves and leaf bases. 

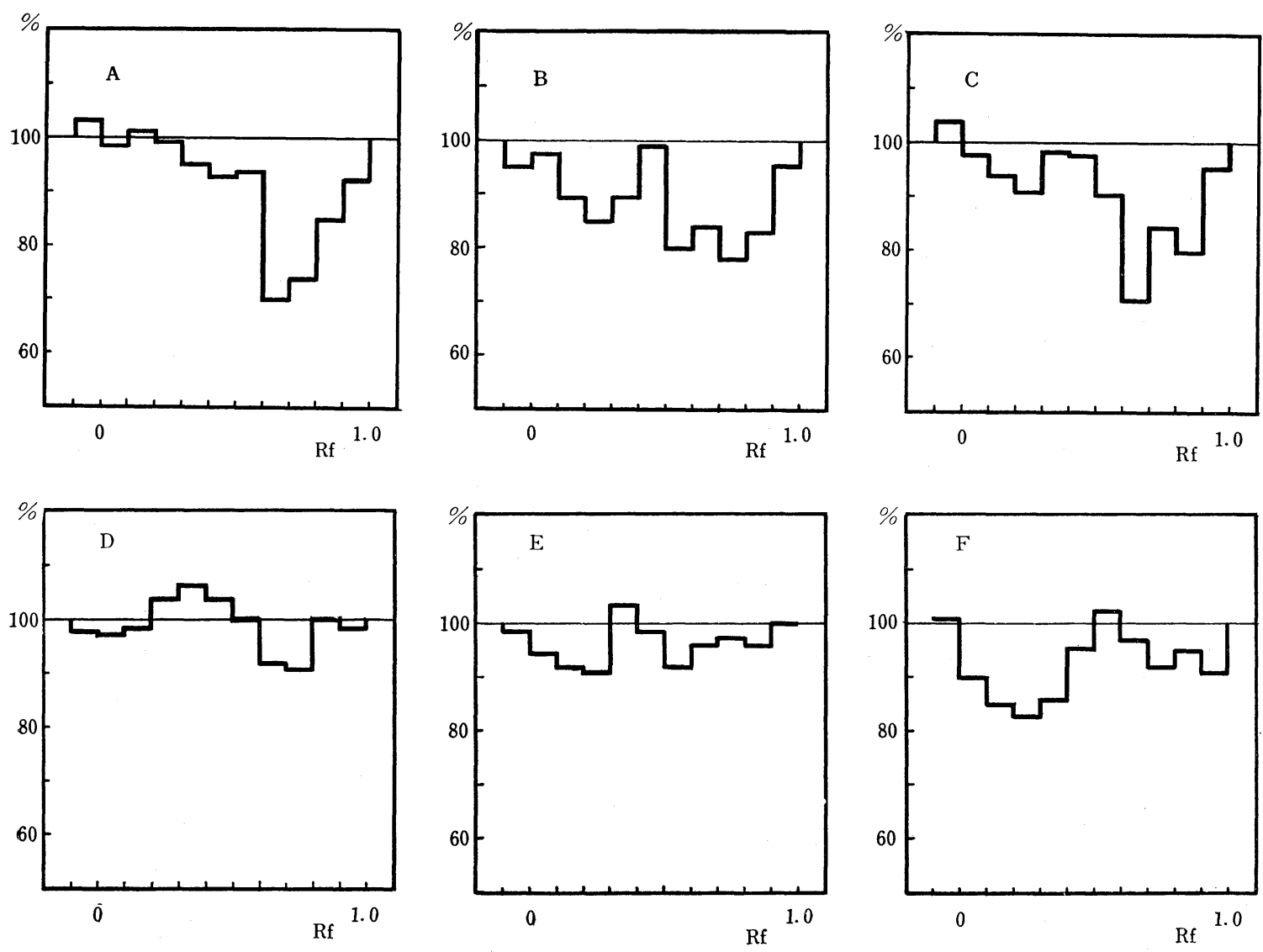

Fig. 4. Results of rice seedling test for extracts from leaves sampled a week after the treatment.

A. extracts from the base of the leaves of the control plant

B. extracts from the sheath leaves of the control plant

C. extract from the base of leaves of plant without sheath leaves

D. extracts from the base of the leaves of plant shaded at the base of the leaves

E. extracts from the sheath leaves of plant shaded at the base of the leaves

F. extracts from the top of the leaves of the control plant

On the other hand, two inhibitory zones were observed at $\operatorname{Rf} 0.1-0.3$ and $\operatorname{Rf} 0.5-$ 0.8 with the same quantitative trend in the extract from leaf bases without sheath leaves, and from the sheath leaves of control plants.

Fig. $4-F$ shows that a single zone of inhibition occurred at $\operatorname{Rf} 0.1-0.3$ and the inhibitory zone at Rf $0.5-0.8$ was not identified in the extract from leaf tops.

\section{Discussion}

Konoshima and Tsukamoto reported in a previous paper (3) that corms taken from the plants of which the leaf bases had been wrapped with aluminium foil were heavier than corms grown under natural conditions.
On the contrary, corms from plants of which the leaf tops had been shaded or treated with photosynthesis-inhibitors were lighter than corms grown under natural conditions, while sprouting in corms which had been treated in these three ways was well developed compared to control corms.

This phenomenon was further investigated in the present paper.

The end of the thickening period of corms from plants of which the leaf bases had been shaded was similar to that of corms grown under natural conditions. In addition, the increment in weight of corms encouraged by the shading of the leaf base was maintained to the end of corm growth, December 23 . 
These facts suggest that this promotion of corm thickening is not due to the acceleration of the growth rate by the shading of leaf bases.

The thickening of corms of plants from which the sheath leaves had been removed was inhibited but recovered slightly when the leaf bases were shaded.

Therefore, it is considered that the sheath leaf plays an important role in the translocation of photosyntheses, and light at leaf bases affects the translocation.

It might be considered that the inhibitor- $\beta$ (including $\mathrm{ABA}$ ) as a gibberellin antagonist, being synthesized at the leaf base exposed to light, was decreased by shading the leaf bases, so that the translocation was promoted by decrease of inhibitor- $\beta$ or gibberellin accumulation.

Konoshima and Tsukamoto demonstrated in a previous paper (3) an early sprouting in corms from plants shaded at the base or the top of the leaves.

In parallel with these results, in the extract of corms from plants shaded at the leaf bases, the content of inhibitor- $\beta$ complex was smaller than in that of corms from plants shaded at the leaf tops or grown under natural conditions, and contrarily a smaller amount of inhibitors at $\mathrm{Rf} 0.1-0.3$ was observed in the extract of corms from plants shaded at the leaf tops than in the extract of corms from plants shaded at the leaf bases or grown under natural conditions.

We presume for gladiolus corms that there are two systems of inhibitor synthesis relating to light.

Wright (11) observed an increase in inhibitor $-\beta$ in leaves exposed to light.

Tillberg (8) reported that a large amount of inhibitor $-\beta$ complex in bean leaves exposed to light was observed as compared with etiolated leaves.

Therefore it might well be concluded that in gladiolus leaves the synthesis of inhibitor$\beta$ is activated by light.

There are few reports on the location of inhibitor synthesis in herbaceous plants, while for arboreous plants many authors have reported that inhibitors are synthesized in the leaf.
Yoshimura and Tagawa (12) pointed out that a neutral growth inhibitor was synthesized at actively growing leaf bases, though this was not clear for inhibitor- $\beta$

It was demonstrated in this study, that when the base of the leaves was shaded, whether the sheath leaves were removed or not, the sprouting of corms was developed in comparison with corms from plants open to light at the leaf bases. In conjunction with this, a decrease of inhibitor- $\beta$ in sheath leaves, leaf bases and corms was observed in plants of which the leaf base was shaded.

Therefore it might be concluded that the sheath leaves, which envelope the base of the leaves located inside them, are one of the principal organs in inhibitor- $\beta$ synthesis.

In the extracts from the sheath leaf and the leaf base from which the sheath leaf had been removed two inhibitors or inhibitor groups were observed on the paper chromatogram at $\operatorname{Rf} 0.1-0.3$ (inhibitor I) and inhibitor- $\beta$ complex (at Rf $0.5-0.8$ ).

On the other hand, the inhibitors were only observed at $\operatorname{Rf} 0.1-0.3$ in the extracts from the top of the leaf or at $\operatorname{Rf} 0.5-0.8$ in the extracts from the leaf base of the plant grown under natural conditions. The treatment of shading the leaf bases decreased the inhibitors at Rf $0.5-0.8$ in the extracts from the sheath leaves and the leaf bases.

These results show that inhibitor $I$ and inhibitor- $\beta$ are synthesized respectively in different parts; in leaves, inhibitor I is synthesized at the top of the leaf which is actively photosynthesizing, and inhibitor- $\beta$ is mainly synthesized at the base of the leaf under the influence of light without direct dependence on current photosynthesis.

It may be indicated that the decrease of inhibitor- $\beta$ which resulted from shading the leaf bases promoted thickening of corms and their germination.

\section{Acknowledgements}

We are grateful to Professor T. Asahira, Kyoto University, for suggestions helpful to this study.

\section{Literature cited}

1. EAGLES, C. F. and P. F. WAREING. 1964. The 
role of growth substances in the regulation of bud dormancy. Physiol. Plant. $17: 697-$ 709.

2. KOHLER, D. and A. LANG. 1963. Evidence for substances in higher plants interfering with response of dwarf peas to gibberellin. Plant Physiol. 38 : 555-560.

3. Konoshima, H. and Tsukamoto, T. 1977. Effects of light condition on the dormancy of the gladiolus corm. J. Japan Soc. Hort. Sci. $45: 414-420$.

4. MASUDA, Y. 1962. Effect of light on a growth inhibitor in wheat roots. Physiol. Plant. 15 : 780-790.

5. OGAWA, Y. 1963. Studies on the conditions for gibberellin assay using rice seedling. Plant \& Cell Physiol. 4 : 227-237.

6. Phillips, I. D. J. and P. F. WAREING. 1959. Study in dormancy of Sycamore II. The effect of daylength on the natural growth-inhibitor content of the shoot. J. Exp. Bot. $10: 504-$ 514.

7. ShibaokA, H. 1961. Studies on the mecha- nism of grow th inhibiting effect of light. Plant \& Cell Physiol. 2 : 175-197.

8. TILlBERG, E. 1974. Levels of indol-3 y1-acetic acid and acid inhibitors in green and etiolated Bean seedlings (Phaseolus vulgaris). Physiol. Plant. $31:$ 106-111.

9. TUCKER, D.J. and T. A. MANSFIELD. 1972. Effect of light quality on apical dominance in Xanthium strumarium and the associated changes in endogenous levels of abscisic acid and cytokinins. Planta $102: 140-151$.

10. VALIO, I. F.M. and W. W. Schwabe. 1970. Growth and dormancy in Lunularia cruciata (L.) VII. The isolation and bioassay of lunularic acid. J. Exp. Bot. 21 : 138-150.

11. WRIGHT, S.T. 1969. An increase in the "inhibitor- $\beta$ " content of detached wheat leaves following a period of wilting. Planta $86: 10-20$.

12. Yoshimura, F. and T. TAGAWA. 1961. Growth regulator in germinating rice seed. J. Fac. Agr. Hokkaido Univ. 51 : 559-573.

\section{グラジオラス球茥の休眠誘導に和ける葉の役割について \\ 木島 温 夫, 塚本洋太郎 \\ （滋賀大学教育学部, 京都大学農学部)}

\footnotetext{
摘 要

グラジオラス球茎の休眠は，栽培期間中の光条件によ って大きく影響されることを明らかにして来たが，本報 告では，葉ならびに葉基部の役割を検討しまとめた.

1. グラジオラスの植物体の基部 $20 \mathrm{~cm}$ を出芽時ある いは本葉 3 枚展葉時よりアルミホイルで包みしゃ光する と, 無処理のものに比べ, 新球茎重は顕著に増大し, こ の新球茎重の差異は肥大停止時に批いて子維持されてい た。

一方鞘葉を除去したものでは新球茎重は著しく減少し た。

2. 植物体の基部をしゃ光すると，完全な植物体と鞘 葉を除去したものは共に新球茎の発芽が無処理に比べ促

進された。

一方鞘葉除去のみのものの新球茎は無処理と同様に発 芽が遅れた.

3. 新球茎の酢酸エチル酸性分画の抑制物質のうち, ペーパークロマトグラム（展開溶媒：イソプロピールア ルコール:アンモニア: 水 $10: 1: 1 \mathrm{v} / \mathrm{v})$ の $\operatorname{Rf}$ 值 0.5 $\sim 0.8$ 亿認められる抑制物質は, 鞘葉を除去したものの 新球茎では無処理と同様に多量に存在したが，葉基部を しゃ光したものの新球茎では顕著に減少していた.

4. 乙ゃ光処理後 1 週間目の葉内では, Rf 值 $0.5 \sim$ 0.8 飞存在する抑制物質が, 無処理葉に比べて顕著に減 少していた.
} 